\title{
Experimental and numerical distribution of pressure on the abutment with backfill from tyre bales
}

\author{
Aleksander Duda ${ }^{1, *}$, Tomasz Siwowski ${ }^{1}$ \\ ${ }^{1}$ Rzeszow University of Technology, Faculty of Civil and Environmental Engineering and Architecture, Aleja Powstańców Warszawy \\ 12, 35-959 Rzeszów, Poland
}

\begin{abstract}
This article describes the tests of the pressure distribution on bridge abutment generated by the backfill made of the recycled car tyres compressed in the form of bales with interfaces of medium sands and a buffer layer with tyre shreds. Backfill pressure distribution was measuring continuously over a period of three months using a pressure sensors. Static and dynamic load tests of abutment were conducted and cyclic horizontal displacements of the abutment wall, as a simulation of thermal elongation / shortening of the bridge span were also performed. The results of pressure field measurements were compared with results of numerical analysis performed using the GEO5 program basing on finite element method. Compatibility results of field measurements and numerical analysis was pretty good, and the maximum difference was about $25 \%$. Based on field measurements and numerical analysis, a $2 \div 4$ times reduction of pressure on bridge abutment was found, if the tyre bales had been used, compared to conventional backfilling of medium sand.
\end{abstract}

\section{Introduction}

Used car tyres are an extremely durable waste that does not natural decomposition and exhibits water resistance, various chemicals and extreme temperatures. Currently in Poland the management of used car tyres consists of: material recycling (high energy granulation) and energy recovery (burning tyres in cement kilns). There are no pro-ecological solutions, such as product of tyre recycling process, which reuses low-processed waste to obtain products with new desired features [1].

In the case of used tyres, product of tyre recycling process consists in grinding tyres to the fraction of shreds (dimension $50 \div 300 \mathrm{~mm}$ ), using whole tyres or their compressing to bales. Rubber material from tyres recycling in the form of bales is best suited for application in civil engineering, especially in transport infrastructure, geotechnics and hydrotechnics [2]. This form of recycling uses the unique properties of tyres, in particular: low volumetric weight, good thermal and acoustic insulation, properties drainage, vibroinsulation and good mechanical properties. Tyre bales were first applied in 1997 in the USA. Since then, over 30 projects have been implemented, mainly in the USA and Great Britain. The most spectacular application of tyre bales was filling of a motorway embankment in Marston Moretaine, Great Britain in 2010 [3].

Roads and Bridges Department at Rzeszow University of Technology conducts laboratory and field tests on the innovative materials from used car tyres pressed into the form of bales. In laboratory tested:
- shear strength of geocomposites which consist of tyre bales and filling materials such as rubber aggregate, expanded clay aggregate and natural aggregate [4],

- stiffness of tyre bales,

- load capacity of wires connecting tyre bales and wire connections.

Field tests conducted at a large-sized demonstrator of the integral abutment and the approach section on the embankment. Scope of field tests include $[5,6]$ :

- the tests on vibration damping by the embankments filled with tyre bales,

- to determine the value and the distribution of pressure on the retaining structure of the geocomposite made up of tyre bales and backfill, under the conditions of backfill load, static and dynamic load of the subgrade,

- deformations of the approach section to the integral bridge abutment, whose backfill has been made from tyre bales and filling material,

- environmental tests of tyre bales.

The article describes the tests of the force pressure distribution on the abutment with backfill in the form of tyre bales with interface from medium sands and a buffer layer of tyre shreds, placed between the wall and tyre bales. The results of field measurements were compared with pressure distribution obtained from the numerical analysis conducted at GEO5 program using finite element method (FEM).

\section{Tyre bales}

Tyre bales from compressed used car tyres are a new recycled building material from product recycling

\footnotetext{
* Corresponding author: aduda@prz.edu.pl
} 
process. Tyre compressing and packaging used tires is a solution resulting from the necessity to limit the sizes of landfill sites and to reduce the risk of spontaneous combustion of tyres there. Compressed tyres are bound with plastic strips or galvanised steel wires of high strength. Finally, tyre bale looks like a rectangular (Fig. 1) whose height corresponds the maximum height of compressed tyres, width results from the size of the press and length depends on the number of compressed tyres (most often 100-135) [5, 6]. The process of tyre pressing and packaging applied in Great Britain has been presented in details in the specification [7], describing the production method and tyre bales dimensions.

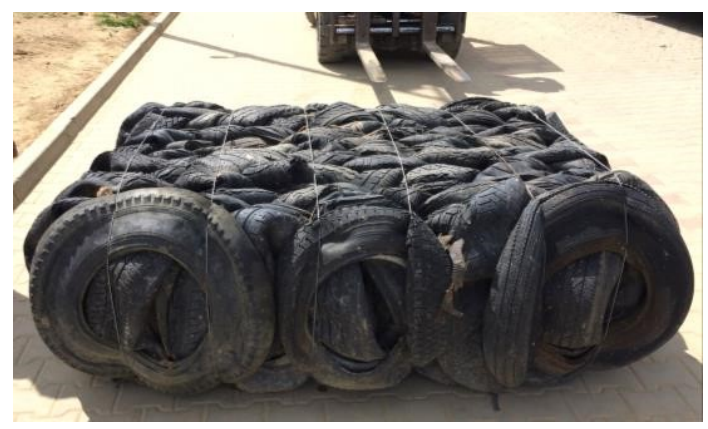

Fig. 1. Tyre bale.

Table 1 presents basic properties of tyre bales, which are mostly more favourable than analogous properties of natural aggregates. One of the crucial drawbacks of the tyre bales is their high compressibility which results from the small values of deformation modulus. This problem can be equalised by means of suitable design and construction solutions, e.g. in embankments, transmission layers of suitable depth of primary aggregates are applied above tyre bales. Such a transmission layer reduces the deformations of the road surface, from live loads due to the deformability of tyre bales to the acceptable level.

Table 1. Comparison of the properties tyre bales with natural aggregates.

\begin{tabular}{|c|c|c|c|}
\hline Feature & $\begin{array}{c}\text { Tyre } \\
\text { bales }\end{array}$ & $\begin{array}{c}\text { Minerals } \\
\text { (sand, } \\
\text { gravel) }\end{array}$ & Source \\
\hline $\begin{array}{c}\text { Unit weight } \\
\mathrm{kN}^{*} \mathrm{~m}^{-3}\end{array}$ & $5 \div 6$ & $18 \div 20$ & {$[7]$} \\
\hline $\begin{array}{c}\text { Friction angle } \\
\left({ }^{\circ}\right)\end{array}$ & $35 \div 36$ & $35 \div 40$ & {$[7,8,9]$} \\
\hline $\begin{array}{c}\text { Elastic modulus } \\
\text { MPa }\end{array}$ & $0,8 \div 1,3$ & $40 \div 100$ & {$[7]$} \\
\hline $\begin{array}{c}\text { Permeability } \\
\text { coefficient } \\
\text { cm/s }\end{array}$ & $2 \div 4$ & $0,1 \div 1$ & {$[7]$} \\
\hline $\begin{array}{c}\text { Thermal } \\
\text { conductivity } \\
\mathrm{W} /(\mathrm{m} * \mathrm{~K})\end{array}$ & 0,07 & $0,4 \div 0,7$ & {$[8]$} \\
\hline \multicolumn{2}{|c|}{}
\end{tabular}

\section{Large-scale stand for field tests}

Field tests of bridge abutment with backfill from tyre bales were carried out on a special test stand simulating the real behaviour of the abutment and the approach section. The test stand includes:

- test chamber (Fig. 3., Fig. 4.),

- access section (Fig. 2 , Fig. 4.).

The test chamber has dimensions in the plan on the outer contour of $6.1 \times 7.75 \mathrm{~m}$, along the internal contour $5.0 \times 6.5 \mathrm{~m}$ and made of steel sheet piles GU16N, length $8 \div 10 \mathrm{~m}$, topped with reinforced concrete cap. Chamber consists of two parts: test and measurement, separated by a movable measuring wall. The measuring chamber with dimensions of $1.5 \times 5.0 \mathrm{~m}$ is used for the installation of measuring instruments (force sensors, actuators, displacement sensor), their cabling and the stand inspection. The test chamber is designed for different variants of backfills and has dimensions of $5.0 \times 5.0 \mathrm{~m}$. The chamber depth is: $6.0 \mathrm{~m}$ and $5.38 \mathrm{~m}$, respectively in the measuring and test part. The measuring wall is divided into 3 panels, which the middle one is a measuring panel where the pressure sensors are installed. Each panel has a height of $5.75 \mathrm{~m}$ and width of $1.66 \mathrm{~m}$. Each panel consist of a $0,15 \mathrm{~m}$ thick reinforced concrete slab with a length of $5.0 \mathrm{~m}$, composite with two steel sections HEB 340, placed in a spacing of $1.35 \mathrm{~m}$. The profiles are attached to the bottom plate by hinged with a bolt connection. Road approach section has one carriageway with one $3 \mathrm{~m}$ traffic lane. Length of approach section is $22 \mathrm{~m}$, includes three section:

- $10 \mathrm{~m}$ with built-in two layers of tyre bales,

- $8 \mathrm{~m}$ with built-in one layer of tyre bales,

- $4 \mathrm{~m}$ reference section without bales.

Above the layer of tyre bales was built a transmission layer with natural aggregate, $0.7 \mathrm{~m}$ thick, cement-sand base course with a thickness of $0,1 \mathrm{~m}$ and pavement with concrete cubs with a thickness of $0.08 \mathrm{~m}$.

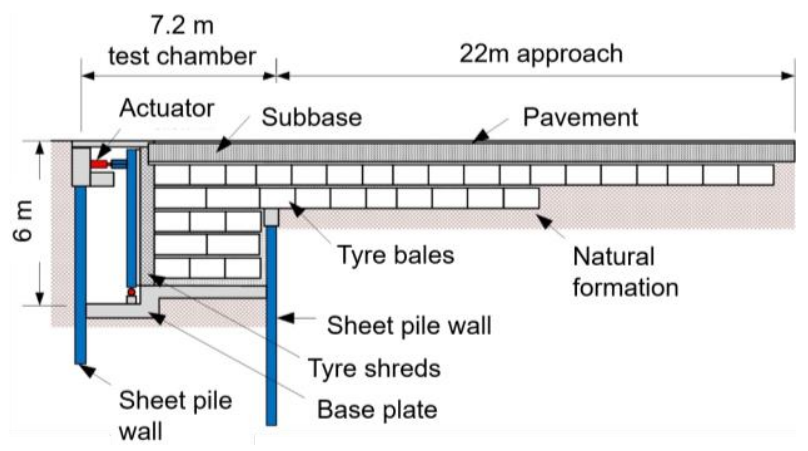

Fig. 2. Scheme of the test stand with road approach section. 


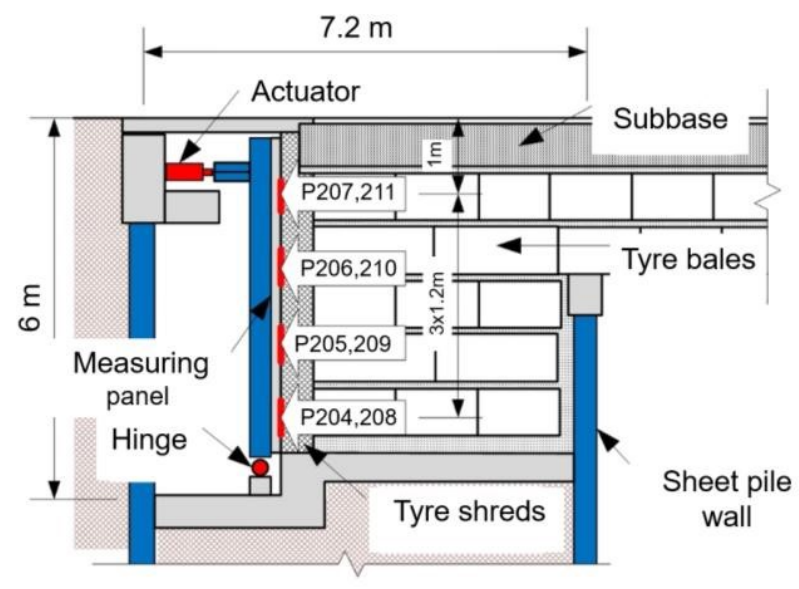

Fig. 3. Arrangement of pressure sensors (P204-P211) in test chamber.

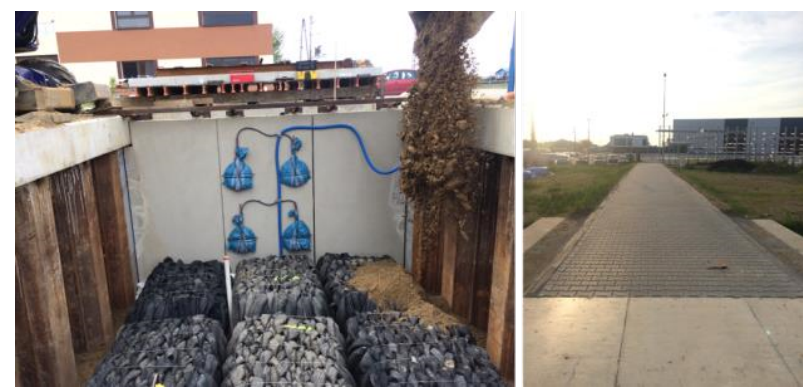

Fig. 4. Pressure sensors installed on the measuring wall during performing backfill (left); all approach section (right).

\section{Program and course of research}

\subsection{Research program}

Tests of backfill pressure for a designed scheme of chamber was planned: tyre bales with backfill of medium sand and buffer layer of rubber shreds. The research included five stages:

I. Static and dynamic loads tests (loading with road plates, vehicle weighing $32 \cdot 10^{3} \mathrm{~kg}$ ),

II. Cyclic imposed displacement of the upper part the measuring wall by $\pm 15 \mathrm{~mm}$ (867 cycles),

III. Cyclic imposed displacement of the upper part the measuring wall by $\pm 30 \mathrm{~mm}$ (1309 cycles),

IV. Cyclic imposed displacement of the upper part the measuring wall by $\pm 45 \mathrm{~mm}$ ( 575 cycles),

V. Retesting under static and dynamic load (loading with road plates, vehicle weighing $32 \cdot 10^{3} \mathrm{~kg}$ ).

The pressure distribution in stages I and $\mathrm{V}$ simulates the work of traditional, cantilevered abutments, while in stages II $\div$ IV - for integral abutments (thermal influences). The number of cycles from actuators forcing the displacement of the measuring wall in stages II, III and IV is defined as the average value for representative thermal extensions for 30 years (designed pavement durability) for a typical bridge with total length of $120 \mathrm{~m}$ (Fig. 5.). The number of cycles and displacement values were adopted on the basis of temperature measurements in the period 1970 - 2000 [10] and recommendations of the standard [11].

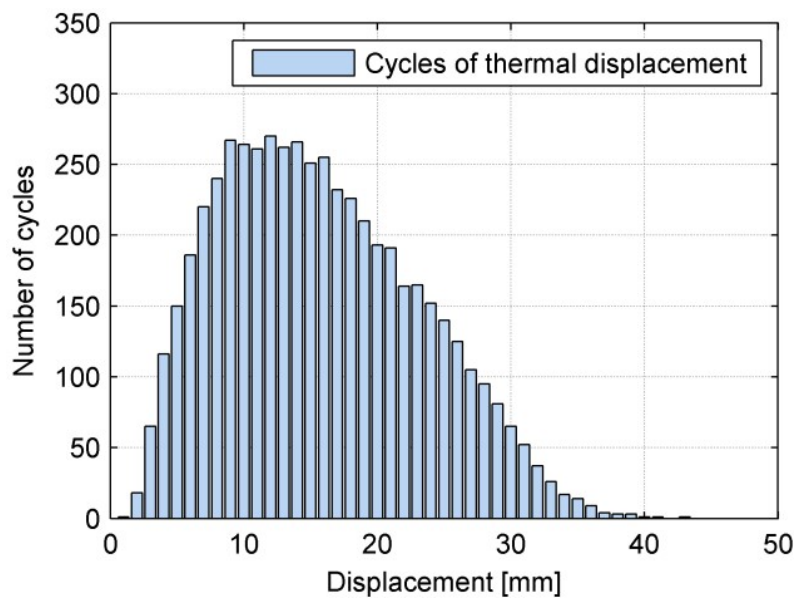

Fig. 5. Cycles of thermal displacements for the composite $120 \mathrm{~m}$ long bridge [10].

\subsection{Course of research}

Cyclic imposed displacement of the measuring wall in stages II, III and IV were carried out using a hydraulic press, controlled by the operator at the speed of $0.5 \div 1.0$ $\mathrm{mm} /$ minute. During the tests, measurements were made: - pressure on the measuring wall (8 sensors),

- acting force on wall displacement (2 sensors),

- temperature in the backfill (10 sensors),

- horizontal wall deflection (2 sensors),

- deformation of the pavement structure (using geodetic leveling).

Registration of measurements of pressure forces, forces generated by actuators and temperatures were performed automatically every 3 minutes. The measurement data was collected using the OMNIA CAB2 acquisition system. Recording of horizontal wall deflections occurred automatically with a frequency of $10 \mathrm{~Hz}$. The measurement data were collected using the Spider type HBM acquisition system. The accuracy of deformation measurements by means of surveying levelling was \pm $0.25 \mathrm{~mm}$.

\section{Numerical model}

\subsection{Model of the test stand}

The numerical model of the test stand was made in the GEO5 program in the FEM module, in 2D space. A working area of $42.5 \times 20 \mathrm{~m}$ was modelled using a triangular and quadrangular mesh elements of $0.4 \mathrm{~m}$ (Fig. 6). The model reproduces: soil in the ground, concrete foundation plate of the test stand, measuring wall, walls of the test chamber made of steel sheet piles, arrangement of layers materials in the test chamber and into approach section. The measuring wall and walls of chamber from sheet pile were modelled with beam elements. 


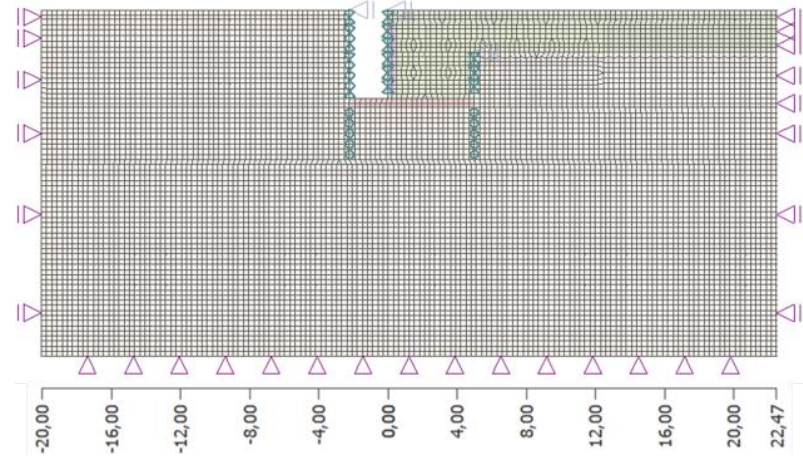

Fig. 6. Dimensions area of the model with finite elements mesh and an arrangement of modelled layers.

Modelling of load on the test stand, the real phases performed test stand were included (excavation, construction), backfilling the test chamber and forced horizontal displacements of the upper part of the measuring wall with of 15,30 and $45 \mathrm{~mm}$ (stages II $\div$ IV) .

\subsection{Material models of the soils and tyre bales}

In the numerical model, 2 material models of stressstrain relation were adopted:

- elastic model (according to Hooke's law) for: buffer layer made of rubber scraps, concrete foundation slab and tyre bales,

- Coulomb-Mohr model for: soil in the ground, subbase with aggregate and backfill with medium sand.

Tables 2 and 3 shows material characteristics adopted for the numerical analysis.

Table 2. Materials characteristics for elastic model

\begin{tabular}{|l|c|c|c|c|}
\hline Material & $\begin{array}{c}\text { Elastic } \\
\text { modulus } \\
{[\mathbf{M P a}]}\end{array}$ & $\begin{array}{c}\text { Poisson's } \\
\text { number } \\
{[-]}\end{array}$ & $\begin{array}{c}\text { Unit } \\
\text { weight } \\
{\left[\mathbf{k N} \cdot \mathbf{m}^{-3}\right]}\end{array}$ & Source \\
\hline Base plate & 32000 & 0,2 & 25 & {$[12]$} \\
\hline Tyre shreds & 0,8 & 0,25 & 5,0 & {$[13]$} \\
\hline Tyre bales* & 12,75 & 0,1 & 7,0 & {$[5,8]$} \\
\hline $\begin{array}{l}\text { * value of unit weight and elastic modulus averaged taking } \\
\text { the height of tyre bales equal to } 0.8 \mathrm{~m}\end{array}$ \\
\hline
\end{tabular}

Table 3. Materials characteristics for soils.

\begin{tabular}{|c|c|c|c|c|c|}
\hline Material & $\begin{array}{c}\text { Elastic } \\
\text { modulus } \\
{[\mathbf{M P a}]}\end{array}$ & $\begin{array}{c}\text { Poisson's } \\
\text { number } \\
{[-]}\end{array}$ & $\begin{array}{c}\text { Unit } \\
\text { weight } \\
{\left[\mathbf{k N} \cdot \mathbf{m}^{-}\right.} \\
\left.{ }^{3}\right]\end{array}$ & $\begin{array}{c}\text { Friction } \\
\text { angle } \\
\gamma\left[{ }^{\circ}\right]\end{array}$ & $\begin{array}{c}\text { Cohesion } \\
{[\mathbf{k P a}]}\end{array}$ \\
\hline $\begin{array}{c}\text { Ground 1 } \\
\text { fine } \\
\text { sand* }\end{array}$ & 50 & 0,3 & 19 & 30 & 0 \\
\hline $\begin{array}{c}\text { Ground 2 } \\
\text { silty } \\
\text { sand* }\end{array}$ & 30 & 0,3 & 19 & 22 & 10 \\
\hline $\begin{array}{l}\text { Subbase } \\
\text { medium } \\
\text { sand** }\end{array}$ & 80 & 0,25 & 18,5 & 35 & 0 \\
\hline $\begin{array}{l}* \text { based on own research } \\
\text { ** based on [6] }\end{array}$
\end{tabular}

\section{Results and discussion}

Figures $7 \div 14$ shows results of field measurements from pressure sensors $($ P204 $\div$ P211) together with results of numerical analysis for two backfill materials: tyre bales for wall displacements in the range $0 \div 45 \mathrm{~mm}$ and conventional backfill with medium sand for wall displacements in range $0 \div 15 \mathrm{~mm}$. Figures 15 and 16 shows results of forces in actuators from field measurements $(\mathrm{S} 1, \mathrm{~S} 2)$ together with results of numerical analysis for backfill with tyre bales and buffer layer from tyre shreds for wall displacements in range $0 \div 45 \mathrm{~mm}$. Figures 17 shows results of geodetic measurements measured along the longitudinal axis of the test stand.

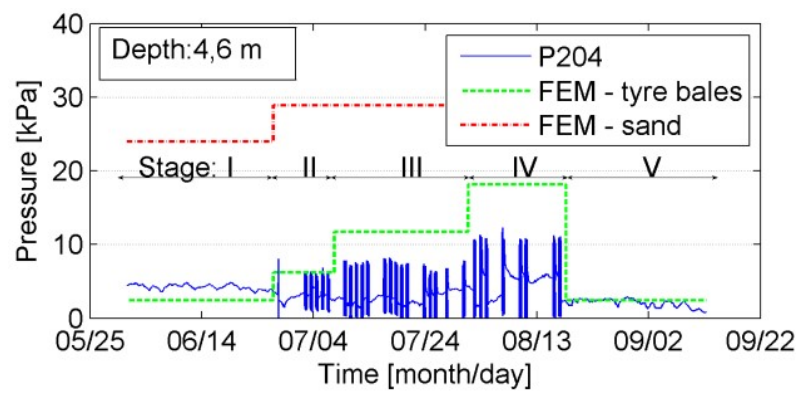

Fig. 7. Pressure distribution for sensor P204 with measurement and FEM.

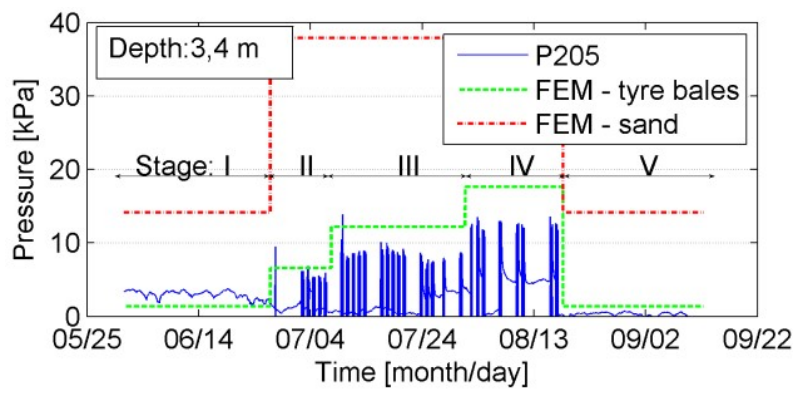

Fig. 8. Pressure distribution for sensor P205 with measurement and FEM.

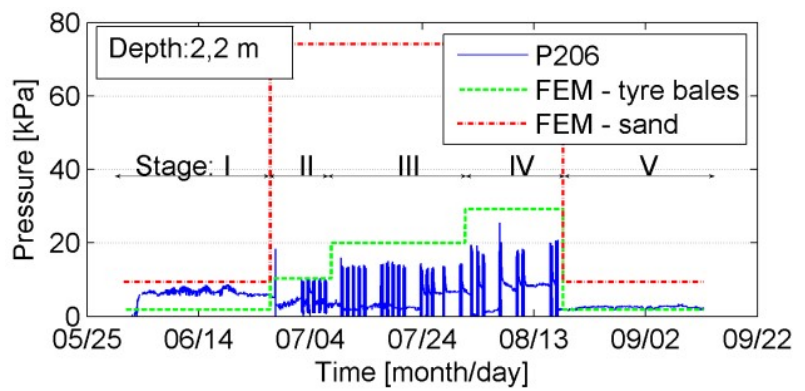

Fig. 9. Pressure distribution for sensor P206 with measurement and FEM. 


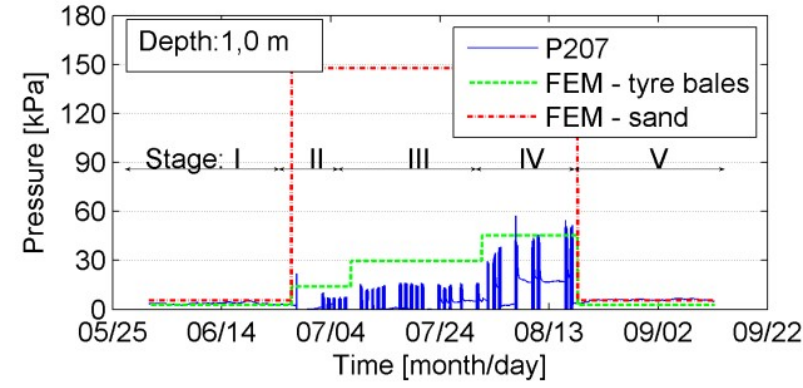

Fig. 10. Pressure distribution for sensor P207 with measurement and FEM.

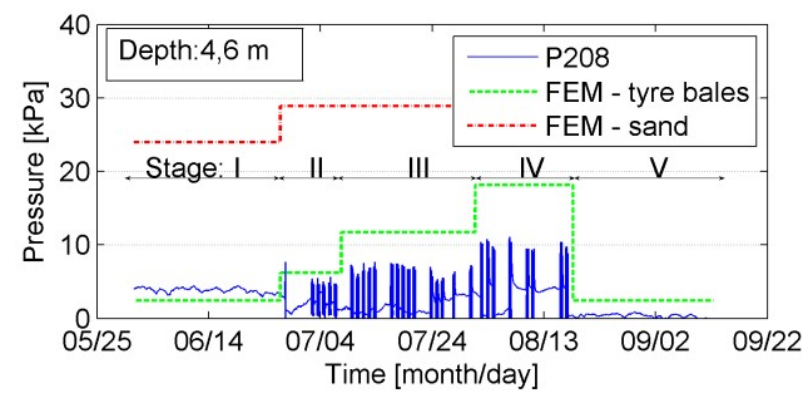

Fig. 11. Pressure distribution for sensor P208 with measurement and FEM.

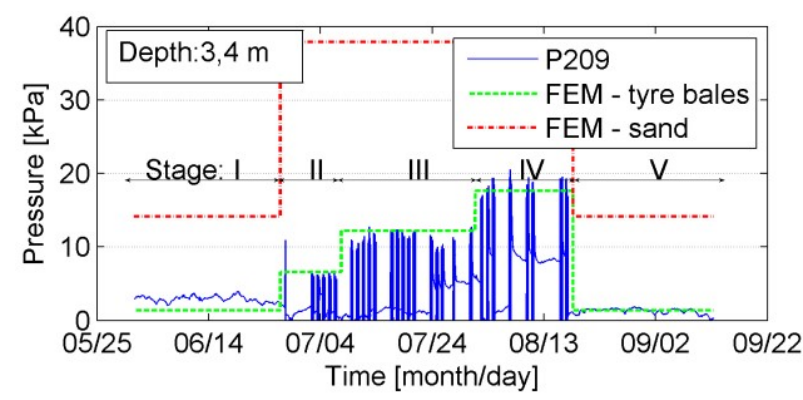

Fig. 12. Pressure distribution for sensor P209 with measurement and FEM.

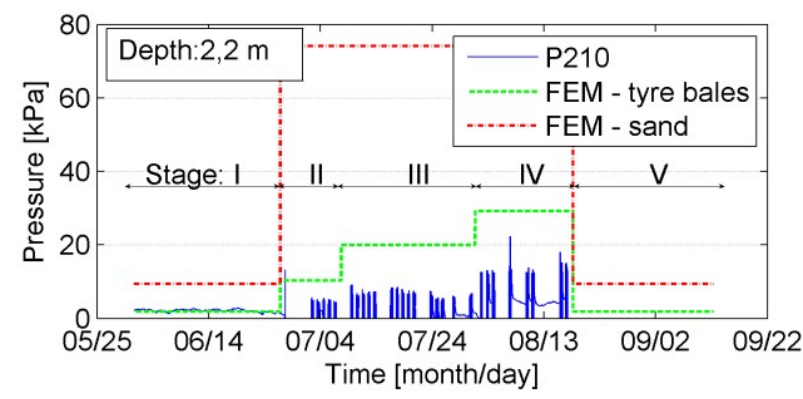

Fig. 13. Pressure distribution for sensor P210 with measurement and FEM.

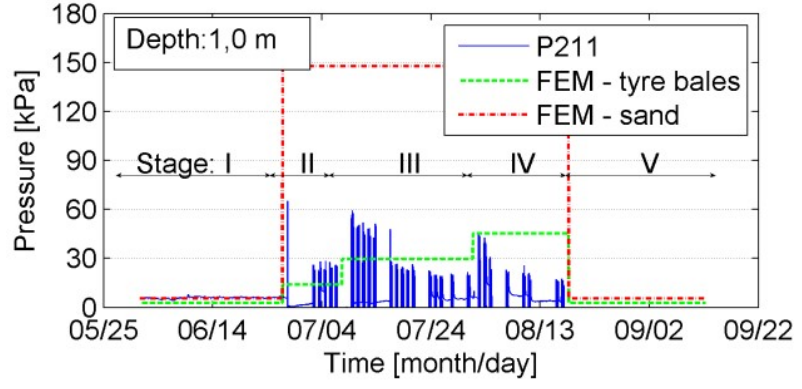

Fig. 14. Pressure distribution for sensor $P 211$ with measurement and FEM.

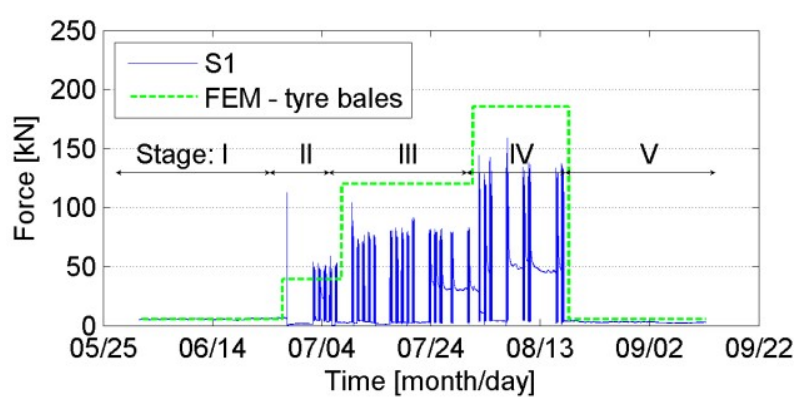

Fig. 15. Force distribution for sensor S1 with measurement and FEM.

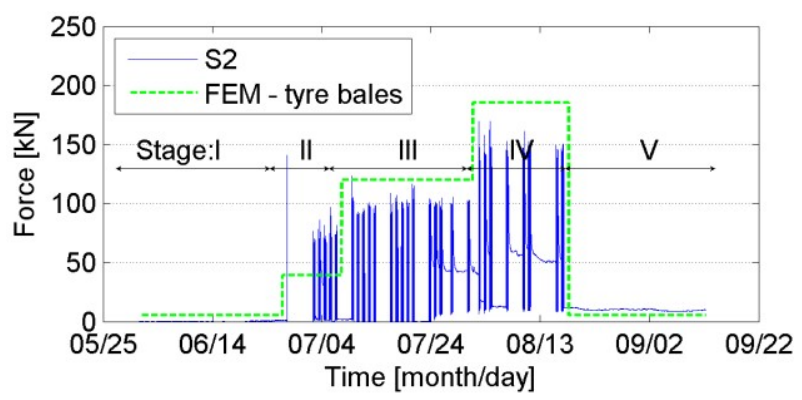

Fig. 16. Force distribution for sensor S2 with measurement and FEM.

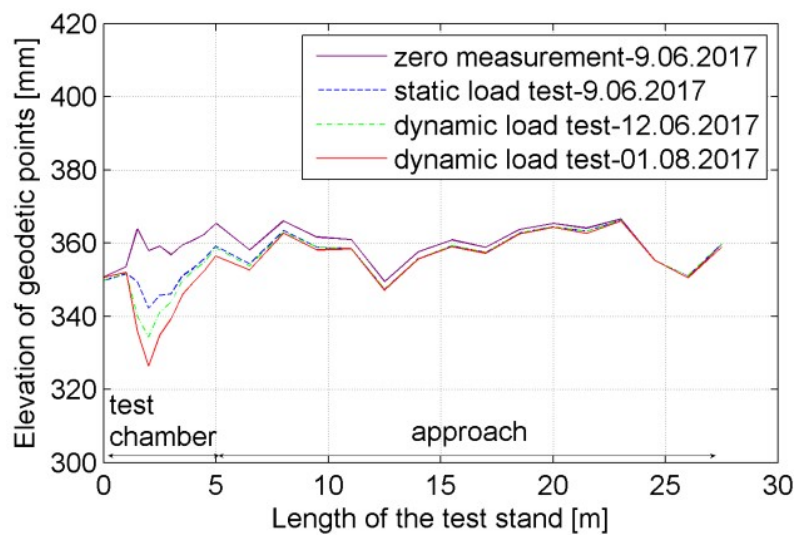

Fig. 17. Geodetic measurements of elevation the pavement structure in test stand.

The analysis of the diagrams (Fig. $7 \div 16$ ) allows to estimate the discrepancy of results from the numerical model with field measurements at the level of $25 \%$ (average value for 8 pressure sensors and 2 force sensors), where almost always measured values are smaller than those obtained from the numerical model. 
Differences between measurements and the numerical model result from:

- adoption in the numerical model of higher rubber materials stiffness (especially in buffer layer from tyre shreds) than obtained in real conditions and determined on the basis of tests,

- influence of temperature on the distribution of internal forces (tests was conducted in the summer months).

Quantitative comparative analysis of pressure distribution on bridge abutment (in particular integral abutment) based on the results from tests and numerical analyzes allows to conclude that there is a significant reduction of pressure for rubber materials (tyre bales, tyre shreds) compared to medium sand backfill:

- about 2 times difference for sensors located 1.0 and 2.2 $\mathrm{m}$ below the ground level when vertical wall positioning (displacement $0 \mathrm{~mm}$ ),

- about 4 times difference for sensors located 3.4 and 4.6 $\mathrm{m}$ below the ground level when vertical wall positioning, - about 4 times difference for sensors located 1.0 and 2.2 $\mathrm{m}$ below the ground level when horizontal displacement of wall at $15 \mathrm{~mm}$,

- about 8 times difference for sensors located 3.4 and 4.6 $\mathrm{m}$ below the ground level when horizontal displacement of wall at $15 \mathrm{~mm}$,

Based on account the obtained results of tests and analyzes, it can be concluded that:

- the pressure on the bridge abutment generated by the backfill from tyre bales and buffer layer from rubber shreds has the character of a silo pressure,

- backfill from tyre bales filling the wedge of resistance structure can be treated in the calculations as a stable block, which not generating pressure.

The tests have been performed under the project co-financed with the European Regional Development Fund called "ReUse - Innovative Recycling Materials, Enhancing the Sustainability of Bridge Facilities" (Innotech No. K3 / IN3 / 38/228116 / NCBiR / 15), implemented by the consortium of Remost Debica sp. z o. o., Promost Consulting sp. k. (Leader of consortium), Geotech Rzeszow sp. z o. o. and Rzeszow University of Technology.

Numerical experiments were conducted with the use of MATLAB application, purchased during the realization of project no. UDA-RPPK.01.03.00-18-003/10-00 "Construction, expansion and modernization of the scientific-research base at Rzeszów University of Technology" is co-financed by the European Union from the European Regional Development Fund within Regional Operational Programme for the Podkarpackie Region for the years 2007-2013, I. Competitive and innovative economy, 1.3 Regional innovation system.

\section{References}

1. http://www.etrma.org/uploads/Modules/Documents manager/20131015---statistics-booklet-2013final2.pdf (2013).

2. J. D. Simm, M. J. Wallis, K. Collins. Sustainable Re-Use of Tyres in Port, Coastal, and River Engineering: Guidance for Planning, Implementation, and Maintenance. HRW Report SR 669, Wallingford: HR Wallingford (2004).
3. I. F. Hodgson, S. P. Beales, M. J. Curd. Use of tyre bales as lightweight fill for the A421 improvements scheme near Bedford, UK. Engineering Geology Special Publications, 26, 101-108 (2012). https://doi.org/10.1144/EGSP26.12.

4. A. Duda, D. Sobala, T. Siwowski. Badania wytrzymałości na ścinanie geokompozytów wykonanych $\mathrm{z}$ pakietów sprasowanych zużytych opon i materiału zasypowego. Acta Sci. Pol. Architectura, $\quad \mathbf{1 6} \quad$ (3), 3-12. DOI: 10.22630/ASPA.2017.16.3.01 (2017).

5. A. Duda, D. Sobala. Initial research on recycled tyre bales for road infrastructure applications. SSP Journal of Civil Engineering - Selected Scientific Papers, t. II, z.12, s. 55-62, DOI: https://doi.org/10.1515/sspjce-2017-0019 (2017).

6. A. Duda, D. Sobala, Badania zużytych opon do wykorzystania w budownictwie. Builder, 11, 74-77 (2017)

7. PAS 108:2007 - Specification for the production of tyre bales for use in construction. British Standards Institution (2007)

8. J. G. Zornberg, B. R. Christopher, M. D. Oosterbaan, Tire Bales in Highway Applications: Feasibility and Properties Evaluation. Colorado Department of Transportation, Report No. CDOTDTD-R-2005-2, Denver, Colorado (2005)

9. PN-B-03020:1981. Grunty budowlane Posadowienie bezpośrednie budowli - Obliczenia statyczne i projektowanie.(1981)

10. D. Sobala. Wpływ wybranych czynników meteorologicznych na odkształcenia przęseł mostów stalowych: naturalne oddziaływania termiczne. Praca doktorska. Wydział Inżynierii Lądowej, Politechnika Warszawska, Warszawa. (2002).

11. PN-EN 1991-1-5:2005/NA:2010. Eurokod 1: Oddziaływania na konstrukcje -- Część 1-5: Oddziaływania ogólne -- Oddziaływania termiczne (2010)

12. PN-EN 1992-1-1:2008. Eurokod 2 -- Projektowanie konstrukcji z betonu -- Część 1-1: Reguły ogólne i reguły dla budynków (2008)

13. Geosyntec Consultants, Guidance Manual for Engineering Uses of Scrap Tires. Geosyntec Project No.: ME0012-11 (2008) 